\title{
Tahapan Menggunting Meningkatkan Kemampuan Motorik Halus Anak Usia Dini
}

\author{
Sri Widayati ${ }^{1}$, Kartika Rinakit Adhe $^{2}$, Faradian Nafisa ${ }^{3}$, Ela Faiza Silvia ${ }^{4}$ \\ 1,2,3,4 Universitas Negeri Surabaya \\ Email: sriwidayati@unesa.ac.id
}

\begin{tabular}{|c|c|}
\hline Kata Kunci: & Abstrak \\
\hline $\begin{array}{l}\text { Tahapan } \\
\text { Menggunting, } \\
\text { Motorik } \\
\text { Halus }\end{array}$ & $\begin{array}{l}\text { Penelitian ini dilatar belakangi oleh kemampuan menggunting anak yang masih perlu } \\
\text { ditingkatkan sehingga peneliti memberikan tahapan menggunting dalam proses } \\
\text { meningkatkan kemampuan motorik halus anak. Tujuan dari penelitian ini adalah untuk } \\
\text { meningkatkan kemampuan motorik halus anak dengan tahapan mengunting yang tepat. } \\
\text { Penelitian ini merupakan penelitian tindakan kelas. Penelitian tindakan kelas ini } \\
\text { dilaksanakan dalam dua siklus. Sampel dalam penelitian ini adalah anak kelompok A } \\
\text { yang berjumlah } 22 \text { anak di TK Dharma Wanita Persatuan. Teknik pengumpulan data } \\
\text { yang digunakan adalah observasi dan dokumentasi. Berdasarkan hasil analisis data } \\
\text { diperoleh bahwa tahapan menggunting dapat meningkatkan kemampuan motorik halus } \\
\text { anak pada siklus I sebesar } 81,8 \% \text { meningkat menjadi } 86,4 \% \text { pada siklus II. Hasil } \\
\text { tersebut menunjukkan bahwa tahapan menggunting mampu meningkatkan kemampuan } \\
\text { motorik halus anak. }\end{array}$ \\
\hline Keywords: & Abstract \\
\hline $\begin{array}{l}\text { Cutting } \\
\text { Stages, Fine } \\
\text { Motor Skills. }\end{array}$ & $\begin{array}{l}\text { This research is motivated by the fine motor ability children who still need to be } \\
\text { improved so that researchers provide stages of cutting in the process of improving } \\
\text { children's fine motor skills. The purpose of this study is to improve children's fine motor } \\
\text { skills with the right stages of cutting. This research is a class action research. This class } \\
\text { action research was carried out in two cycles. The sample in this study was group A } \\
\text { children totaling } 22 \text { children in TK Dharma Wanita Persatuan. Data collection } \\
\text { techniques used are observation and documentation. Based on the results of data } \\
\text { analysis, it was found that the cutting stage could increase the fine motor skills of } \\
\text { children in the first cycle by } 81.8 \% \text {, increasing to } 86.4 \% \text { in the second cycle. These } \\
\text { results indicate that the cutting stage can improve children's fine motor skills. }\end{array}$ \\
\hline
\end{tabular}

Submission: December 2, 2019. Revised: December 10, 2019. Accepted: December 12, 2019

\section{A. Pendahuluan}

Perkembangan motorik anak dibagi menjadi dua yaitu motorik kasar dan motorik halus, motorik kasar yaitu aktivitas dengan menggunakan otot-otot besar, meliputi gerak lokomotor, non lokomotor, dan manipulatif. Sementara itu motorik halus yaitu kemampuan anak prasekolah beraktivitas dengan menggunakan otot-otot halus (otot kecil) seperti menulis, menggambar (Samsudin, 2008:15). Perkembangan motorik yang optimal akan mendukung aktivitas sehari hari anak seperti menali sepatu, mengancingkan baju, menarik reselting, memotong kue, dan lain sebagainya (Wardani:2014).

Terkait dengan aktivitas anak di sekolah kegiatan motorik halus anak sangat mendominasi dalam beraktivitas tulis menulis. Sementara motoric kasarnya lebih banyak digunakan pada saat jam istirahat atau jam olah raga. Berhubungan dengan motoric halus Sumantri (2005:146) mengungkapkan bahwa keterampilan motorik halus anak berhubungan dengan gerak kedua tangan, anak mampu menggerakkan anggota tubuh yang berhubungan 
dengan gerak jari jemari seperti: kesiapan menulis, menggambar dan memanipulasi bendabenda.

Kegiatan mengggunting adalah salah satu kegiatan motorik halus yang dapat melatih koordinasi gerakan tangan dan mata. Kelebihan menggunting bagi anak adalah melatih motorik halus, melatih koordinasi tangan-mata dan konsentrasi, meningkatkan kepercayaan diri, lancar dalam menulis dan ungkapan ekspresi. Sumantri (2005: 157).

Hasil observasi ditemukan bahwa kemampuan motorik halus anak dalam menggunting masih perlu ditingkatkan. Hal ini dapat dilihat ketika beberapa anak masih kesulitan dalam hal memegang gunting, mengerakkan gunting serta menggunting sesuai pola tegak dan lengkung. Dengan kreatifitasnya dapat membantu anak untuk mengekspresikan ide serta gagasannya sesuai dengan imajinasi dengan cara memberikan kebebasan kepada anak. Sehingga anak akan mendapatkan pengalaman baru yang memicu munculnya kretifitas sehingga anak lebih mudah mengingat, melihat, mempraktekan dari pengalaman yang ia peroleh, (Allan Firman Jaya, 2019)

Kemampuan menggunting pada seorang individu berkembang bermula dari cara memegang gunting yang benar, bagaimana mengerakkan gunting dan menggunting garis lurus (Mahoney dan Markwell, 2004). Mengajarkan menggunting pada anak diberikan secara bertahap. Hal ini sesuai dengan Peabody Development Motor Scales bahwa anak usia 2 tahun dapat melakukan gerakan buka dan tutup gunting. Selanjutnya anak usia 2,5 tahun dapat menggunting sepanjang $15 \mathrm{~cm}$. Pada usia 3, 5 tahun anak dapat menggunting garis $15 \mathrm{~cm}$ serta pada usia 4 tahun anak dapat menggunting bentuk lingkaran (Folio M dan RR F, 2000).

Bentuk gunting mempengaruhi anak dalam belajar memegang gunting. Bentuk gunting yang baik untuk anak adalah gunting yang didesign oleh Fiskar. Adapun ciri-ciri gunting yang didesain oleh Fiskars untuk anak usia 4-5 tahun yaitu pegangan pada gunting memiliki ukuran lubang yang berbeda dimana lubang yang atas lebih kecil dibandingkan lubang yang bawah. Lubang yang atas diposisikan untuk ibu jari dan lubang yang bawah diposisikan untuk jari tengah, jari manis, jari kelingking dan jari telunjuk digunakan sebagai penahan diluar lubang. Desin gunting dari Fiskar ini terus berkembang terutama dari segi bahan dan ukuran. Untuk keamanan anak maka dipilih bahan dari plastik dengan ujung yang tumpul. Adapun gunting yang digunakan untuk pertama kali anak belajar menggunting sebagai berikut (Nafisah, 2018):

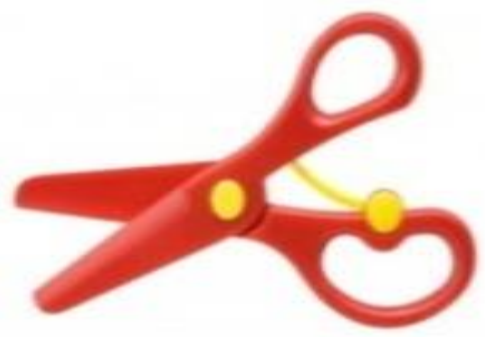

Gambar 1. gunting untuk anak

Rumusan masalah dalam penelitian ini yakni bagaimana tahapan menggunting dapat meningkatkan kemampuan motorik halus anak. Tujuan dalam penelitian yakni untuk mengetahui bagaimana tahapan menggunting dapat meningkatkan kemampuan motorik halus anak. Manfaat dari penelitian ini yakni: a) Bagi peneliti, hasil penelitian ini dapat diajukan acuan untuk mengembangkan penelitian selanjutnya, b) Bagi Guru, dapat dijadikan dasar pedoman dalam mengajarkan menggunting pada anak c) Bagi Lembaga, sebagai dasar dalam membuat program materi berjenjang atau berkesinambungan dari KB ke TK.

Menurut Sumantri (2005:152) menggunting adalah memotong berbagai aneka kertas atau bahan-bahan lain dengan mengikuti alur, garis atau bentuk-bentuk tertentu merupakan salah satu 
kegiatan yang mengembangkan motorik halus anak. Koordinasi mata dan tangan dapat berkembang melalui menggunting.

Sementara itu Hasnida (2014:52) menyatakan bahwa motorik halus adalah gerakan yang menggunakan otot-otot halus atau sebagian anggota tubuh tertentu yang dipengaruhi oleh kesempatan untuk belajar dan berlatih, misalnya kemampuan memindahkan dari tangan, mencoret-coret, meremas, menggenggam, menggunting, menulis dan lain-lainnya.

Penelitian ini sejalan dengan Janah (2016) "Meningkatkan Kemampuan Motorik Halus Melalui Kegiatan Menggunting Dasar Pada Anak Usia 3-4 Tahun di KB Melati Kampung Baru Plandaan Jombang" dan Chabibah (2014) "Peningkatan Kemampuan Motorik Halus Anak Usia 3-4 Tahun Melalui Kegiatan Menggunting Dasar di SPS Al-Muttaqin Jombang. Kedua penelitian diperjelas oleh Suratno (2005:127) bahwa menggunting dapat melatih motorik halus anak, melatih koordinasi mata, tangan dan konsentrasi, meningkatkan kepercayaan diri anak, lancar menulis, ungkapan ekspresi, dan mengasah kognitif.

\section{B. Metode}

Penelitian tindakan kelas ini menggunakan model Kemis dan Mc Taggart yang disajikan dalam bagan:

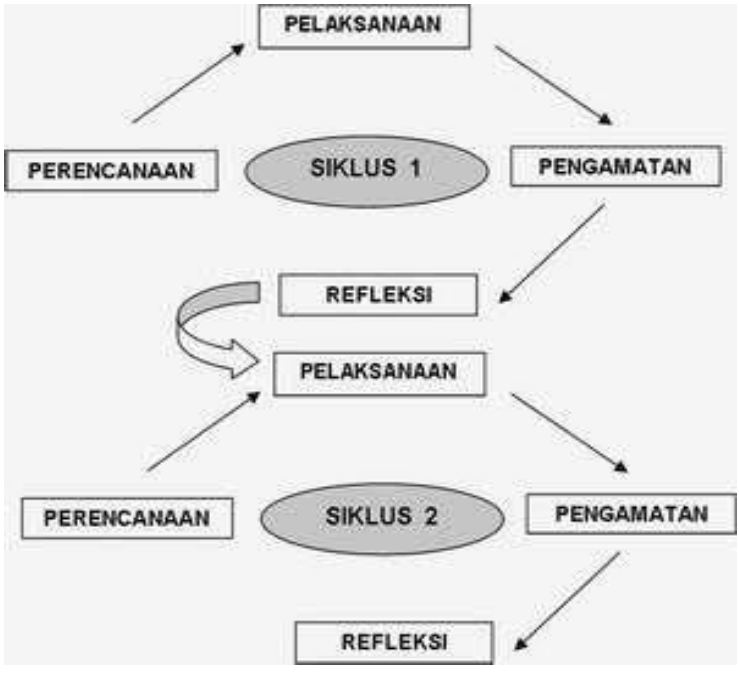

Bagan 1. alur ptk

Subjek penelitian ini seluruh anak kelompok A di TK Gresik yang berjumlah 22 anak. Teknik pengumpulan data dalam penelitian menggunakan teknik pengumpulan data observasi dan dokumentasi (Arikunto, 2008). Instrumen penelitian yang digunakan adalah lembar pengamatan dan mengumpulkan dokumen pendukung. Teknik pengamatan dilakukan sebelum dan sesudah yakni anak mampu menggunting sekitar pinggiran kertas, menggunting potongan kertas dengan lebar 1,5 cm, menggunting dengan separuh bukaan gunting, menggunting garis tebal dengan terkendali, menggunting diantara dua garis lurus, membuka dan menggunting terus menerus sepanjang kertas, menggunting banyak garis lurus (8 garis), menggunting zig-zag, meggunting garis lengkung, menggunting bentuk sederhana (persegi dan segitiga), menggunting bentuk tetapi tidak pada garis, menggunting 1 bentuk spiral, menggunting berbagai macam bentuk (persegi panjang, logo PMI, lingkaran, persegi lima), memegang gunting, dan menggerakkan gunting. 
Teknik dokumentasi dilakukan untuk mencatat peristiwa yang sedang berlangsung. Dalam penelitian ini dokumen-dokumen yang dikumpulkan berupa data kemampuan motorik halus anak dalam menggunting, foto kegiatan pada saat pengamatan berlangsung, dan RPPH.

\section{Hasil Dan Pembahasan}

Penelitian ini dilakukan di TK Gresik. Subjek penelitian yakni anak kelompok A yang berjumlah 22 anak. Penelitian ini menggunakan tahapan menggunting untuk mengetahui kemampuan motorik halus anak kelompok A. Proses pelaksanaan penelitian menggunakan 2 siklus kegiatan.

Pada siklus I kegiatan yang diberikan menggunting; 1) sekitar pinggiran kertas, 2) menggunting potongan kertas dengan lebar $1,5 \mathrm{~cm}, 3$ ) menggunting dengan separuh bukaan gunting,4) menggunting garis tebal dengan terkendali, 5) menggunting diantara dua garis lurus, 6) membuka dan menggunting terus menerus sepanjang kertas, menggunting banyak garis lurus (8 garis). Adapun hasil yang diperoleh mengenai kemampuan motorik halus anak terlihat pada table 1 sebagai berikut:

Tabel 1. Data siklus 1 Kemampuan Motorik halus anak dalam menggunting

\begin{tabular}{|c|c|c|c|}
\hline No & $\begin{array}{c}\text { Kemampuan memegang } \\
\text { gunting } \\
\text { (dengan benar) }\end{array}$ & $\begin{array}{c}\text { Kemampuan } \\
\text { menggerakan } \\
\text { guntting }\end{array}$ & $\begin{array}{c}\text { Hasil guntingn yang rapi } \\
\text { (tidak terputus-putus) }\end{array}$ \\
\hline 1 & 24 & 24 & 24 \\
\hline 2 & 18 & 17 & 17 \\
\hline 3 & 24 & 24 & 24 \\
\hline 4 & 24 & 24 & 24 \\
\hline 5 & 24 & 24 & 24 \\
\hline 6 & 24 & 24 & 24 \\
\hline 7 & 24 & 24 & 24 \\
\hline 8 & 24 & 24 & 24 \\
\hline 9 & 24 & 24 & 24 \\
\hline 10 & 24 & 24 & 24 \\
\hline 11 & 16 & 16 & 24 \\
\hline 12 & 24 & 24 & 24 \\
\hline 13 & 24 & 24 & 16 \\
\hline 14 & 24 & 24 & 24 \\
\hline 15 & 17 & 16 & 24 \\
\hline 16 & 24 & 24 & 24 \\
\hline 17 & 24 & 24 & 24 \\
\hline 18 & 24 & 24 & 24 \\
\hline 19 & 24 & 24 & 24 \\
\hline 19 & 24 & 24 & 17 \\
\hline 20 & 24 & 24 & 24 \\
\hline 21 & 24 & 17 & 24 \\
\hline 22 & 18 & & 2 \\
\hline
\end{tabular}

Pada siklus 1 terdapat 6 jenis kegiatan menggunting dengan kriteria penilaiannya pada suaaltu indicator adalah Berkembang sangat baik $(\mathrm{BSB})=4$, Berkembang sesuai harapan $(\mathrm{BSH})$ $=3$, Mulai Berkembang $(\mathrm{MB})=2$, dan Belum berkembang $(\mathrm{BB})$. Pada table diatas terdapat nilai 24 , yang berarti pada $6 \times$ aktivitas mengunting pada indicator kemampuan memegang gunting maka pada setiap kegiatan anak tersebut memperoleh nilai berkembang sangat baik (BSB). Pada 
nilai di bawah dari 24 maka pada indikator kemampuan tersebut anak tidak semuanya memperoleh berkembang sangat baik. Pada siklus I maka diperoleh data:

$18 \times 100 \%=81,8 \%$

22

Data table 1 yang diperoleh mengungkapkan bahwa 18 orang anak memperoleh rata-rata nilai 4 pada semua indicator, hanya 4 orang anak yang belum memperoleh skor rata rata 4 . Kemudian siklus berlanjut pada siklus ke 2. Adapun yang membedakan dengan siklus ke-2 adalah bentuk kegiatan menggunting lebih tinggi tingkatannya. Kegiatan yang diberikan pada siklus II antara lain: 1) menggunting zig-zag,2) menggunting garis lengkung, 3) menggunting bentuk sederhana (persegi dan segitiga), 4) menggunting bentuk tetapi tidak pada garis, 5) menggunting 1 bentuk spiral, 6) menggunting berbagai macam bentuk (persegi panjang, logo PMI, lingkaran, persegi lima). Pada siklus ke-2 diperoleh data dalam table 2 sebagai berikut:

Tabel 2. Data siklus 2 Kemampuan Motorik halus anak dalam menggunting

\begin{tabular}{|c|c|c|c|}
\hline No & $\begin{array}{c}\text { Kemampuan memegang } \\
\text { gunting } \\
\text { (dengan benar) }\end{array}$ & $\begin{array}{c}\text { Kemampuan } \\
\text { menggerakan } \\
\text { guntting }\end{array}$ & $\begin{array}{c}\text { Hasil guntingn yang rapi } \\
\text { (tidak terputus-putus) }\end{array}$ \\
\hline 1 & 24 & 24 & 24 \\
\hline 2 & 18 & 17 & 24 \\
\hline 3 & 24 & 24 & 24 \\
\hline 4 & 24 & 24 & 24 \\
\hline 5 & 24 & 24 & 24 \\
\hline 6 & 24 & 24 & 24 \\
\hline 7 & 24 & 24 & 24 \\
\hline 8 & 24 & 24 & 24 \\
\hline 9 & 24 & 24 & 24 \\
\hline 10 & 24 & 24 & 24 \\
\hline 11 & 24 & 24 & 24 \\
\hline 12 & 24 & 24 & 24 \\
\hline 13 & 24 & 24 & 17 \\
\hline 14 & 24 & 24 & 24 \\
\hline 15 & 17 & 17 & 24 \\
\hline 16 & 24 & 24 & 24 \\
\hline 17 & 24 & 24 & 24 \\
\hline 18 & 24 & 24 & 24 \\
\hline 19 & 24 & 24 & 24 \\
\hline 19 & 24 & 24 & 24 \\
\hline 20 & 24 & 24 & 18 \\
\hline 21 & 24 & 18 & \\
\hline 22 & 18 & & 24 \\
\hline & & 24 & 24 \\
\hline
\end{tabular}

Berdasarkan tabel diatas maka diperoleh data:

$19 \times 100 \%=86,4 \%$

22

Data table 2 yang diperoleh menunjukkan bahwa terdapat peningkatan 1 orang anak yang mendapatkan indicator rata-rata Berkembang sangat baik $(\mathrm{BSB})=4$. Data table 1 dan table 2 menunjukkan terdapat peningkatan dari $81,8 \%$ menjadi $86,4 \%$.

Hal ini menunjukkan peningkatan sebesar 4,6\% kemampuan motoric halus anak. Peningkatan siklus I dan II tidak terlalu tinggi didasari oleh kegiatan menggunting yang diberikan pada siklus II merupakan kegiatan menggunting yang materinya sudah cukup sulit sehingga untuk anak yang pada siklus I masih belum memperoleh skor rata-rata 4 memerlukan 
proses tambahn kegiatan agar dapat memperoleh nilai rata-rata 4. Hal ini sesuai pendapat Mahoney dan Markwell (2004) bahwa kemampuan menggunting seorang individu berkembang bermula dari cara memegang gunting yang benar, bagaimana mengerakkan gunting dan menggunting garis lurus. Anak yang memiliki kemampuan memegang gunting, mengerakkan gunting dan mengoperasikan gunting dengan tepat berdampak pada hasil akhir guntingan anak. Penelitian ini menemukan bahwa kemampuan motorik halus anak dalam menggunting dipengaruhi oleh frekuensi penggunaan gunting disetiap stimulasi yang diberikan.

\section{Penutup}

Berdasarkan hasil penelitian dapat disimpulkan bahwa tahapan menggunting dapat meningkatkan kemampuan motoric halus anak. Hal ini dibuktikan dengan dengan 81,8\% anak pada siklus 1 telah mendapat skor rata-rata 4 pada semua indikator dan pada siklus 2 terjadi peningkatan menjadi $86,4 \%$ anak yang mendapat skor rata-rata 4 pada semua indicator kemampuan motoric halus. Berdasarkan hasil penelitian tersebut maka penggunaan tahapan pada menggunting anak usia dini sangatlah penting, guru perlu mencermati setiap tahap yang diajarkan. Tahapan yang diajarkan disarankan runtut.

Berdasarkan kesimpulan diatas penelitian yang telah dilakukan dengan judul Tahapan menggunting untuk menimgkatkan kemampuan motorik halus anak usia dini dapat diberikan saran sebagai berikut: Bagi Guru, guru dapat menerapkan tahapan menggunting dalam meningkatkan kemampuan motorik halus anak khususnya menggunting. Bagi pengelola Taman Kanak-Kanak, menyediakan gunting yang tepat dan tahapan menggunting sebagai program/ materi dalam kurikulumnya. Bagi Peneliti Selanjutnya, peneliti lain dapat mengembangkan penelitian lebih lanjut yang terkait dengan kegiatan mengguntik ataupun kegiatan motorik halus lainnya.

\section{Daftar Pustaka}

Arikunto, S. (2010). Prosedur Penelitian Suatu Pendekatan Praktek. Jakarta: Rineka Cipta.

Clarissa, 2018.The Best Scissors to Introduce to Preschoolers.Munchkins and Moms (Online). (http://munchkinsandmoms.com/the-best-scissors-to-introduce-to/ diakses 09 Mei 2018).

Firmanjaya.A. (2019). Strategi Pemanfaatan Aplikasi Kids Center untuk Mengembangkan Kreatifitas Anak Kelompok A di Lingkungan Keluarga. Child Education Journal, 1(1), 7. https://doi.org/10.33086/cej.v1i1.1018

Folio M, RR F. (2000). Peabody Developmental Motor Scales, (PDMS-2). 5th e. Los Angeles: Western Psychological Service.

Hasnida. (2014). Analisis Kebutuhan Anak Usia Dini. Jakarta: PT Luxima Metro Media.

Levin, Vanessa. (2017). How to Teach Scissors Cutting Skills. Pre-K Pages (Online).(https://www.pre-kpages.com/teach-scissor-cutting-skills/ diakses 09 Mei 2018).

Lorina. (2015). Fine Motor Development for Preschoolers 4-5 Years Olds. Aussie Childcare Network (Online). (https://aussiechildcarenetwork.com.au/articles/child-development/ fine-motor-development-for-preschoolers-4-5-year-olds. diakses 27 April 2018).

MOHONEY s, Msrkwell A. (2004). Developing Scissors Skills-A Guide for Parents \& Teachers. Dunmow: Peta (UK) ltd.

Nafisa. 2018. Pengaruh Tahapan Menggunting Terhadap Kemampuan Motorik Halus Anak Kelompok A Di Tk Dharma Wanita Persatuan Randuagung Gresik. Vol.7, No.3.

Pamadhi, Hajar. 2010. Seni Keterampilan Anak. Jakarta: Universitas Terbuka.

Child Education Journal. Volume 1, No. 2 December 2019, 50-57 
Peraturan Menteri Pendidikan Nasional Nomor 137 Tahun 2014.Tentang Standar Tingkat Pencapaian Perkembangan Anak. Jakarta: Departemen Pendidikan Nasional.

Rigg, Diana. (2011). Developping Cutting Skills. PLD Learning Resource (Online). (https://www.healthygc.com.au/MedicareLocal/media/Site-Pages Content/Nurse/Scissor_ Cutting_Skills.pdf diakses 15 Mei 2018).

Samsudin. (2008). Pembelajaran Motorik Di Taman Kanak-Kanak. Jakarta: Prenada Media Group.

Santrock, W John. (2011). Masa Perkembangan Anak. Jakarta: Salemba Humanik.

Sugiyono. (2015). Metode Penelitian Kuantitatif Kualitatif dan $R \&$ \& . Bandung: Alfabeta.

Sumantri. (2005). Model Pengembangan Keterampilan Motorik Anak Usia Dini. Jakarta: Dapartemen Pendidikan Nasional.

Suratno. (2005). Pengembangan Kreativitas Anak Usia Dini. Jakarta: Depdiknas.

Wardani, Ilfi Rahmi. (2017). Meningkatkan Kemampuan Motorik Halus Dengan Kegiatan Bermain Menggunakan Media Plastisin Di Kelompok B Tk Al - Ulya Rajabasa Bandar Lampung. Undergraduate thesis, UIN Raden Intan Lampung.

Zachry, Anne. (2018). Teaching Preschoolers to Use Scissors. Parents Magazine (Online). (https://www.parents.com/toddlers-preschoolers/development/physical/teachingpreschoolers-to-use-scissors/ diakses 27 April 2014). 